WOJCIECH OTTO

Institute of Film, Media and Audiovisual Arts Adam Mickiewicz University in Poznań

\title{
On a construction site - a change of perspectives. Architecture in Polish documentaries of the 1960s
}

\begin{abstract}
Otto Wojciech, On a construction site - a change of perspectives. Architecture in Polish documentaries of the 1960s. "Images" vol. XXII, no. 31. Poznań 2017. Adam Mickiewicz University Press. Pp. 123-134. ISSN 1731-450X. DOI 10.14746/i.2017.31.12.

Film documentaries: Energia [Energy] by Władysław Ślesicki and Czas przemiany [The Time of Transformation] by Andrzej Piekutowski are film examples of changing perspectives in Polish documentary film of the 1960s. The creators undertook the themes known from the socialist realism cinema, such as industrialization and the value of human labour, but they did so in the poetics of authorial cinema, creating films with a deeper, symbolic message and in a lyrical atmosphere.
\end{abstract}

Keywords: film documentary, Polish cinema, Władysław Ślesicki, Andrzej Piekutowski

The 1960 s in domestic cinema abounded in a great variety of events marked by leading trends and tendencies as well as by extraordinary creative personalities[1]. In the vast majority of cases, however, these were not phenomena with expressive time frames and coherent poetic programs. The trend of the "black series", growing from the aura of October 1956 optimism, was coming to an end, leaving behind the air of one-sided criticism of various pathologies and social deviations. Its place was briefly taken by new proposals from the Polish cinema of facts, as it turned out later, definitely more innovative and much more mature, and their value was additionally confirmed by numerous awards received at international film festivals. The "Polish documentary school" [2] was more and more often talked about publicly, with many people looking for an analogy to the achievements of native feature film-makers. However, the term was not yet confirmed in reality. Admittedly, there were many new, extremely talented authors such as: Władysław Ślesicki, Kazimierz Karabasz, Bohdan Kosiński, Jarosław and Andrzej Brzozowski, Danuta Halladin, Janusz Majewski or Jerzy Bossak, who was recognized as the mentor of the school, but the works appearing in following years clearly indicated that the environment of Polish documentary film-makers is too strongly atomized to be able to function within one artistic formation. Therefore, individual creative

[1] Zbigniew Klaczyński writes that in the Polish documentary film of that time two "trends of creativity" were in force: journalistic and poetic. Broader on that: Z. Klaczyński, Dwa nurty w filmie dokumentalnym, "Ekran" 1961, no. 25.

\section{Images} vol. XXII/no. 31 Special Issue Poznań 2017 ISSN 1731-45OX 
personalities and their works, created in the poetics of individually developed styles and methods of describing reality, became the guarantee of success. And so, after just a few years, the discussion forum already had the concept of a "Karabasz school," [3] ennobling social issues and the authenticity of artistic expression, and over time this formula was enriched with considerations of an individual character. After a temporary formal and thematic crisis, noticed in the middle of the decade, [4] there was another revival at the turn of the decades. Representatives of the so-called "new change," in other words an informal generation and programme group separating itself from the directives of a classic documentary expressed through objectivity and "balance of perspective," came to the fore. Its core was constituted by later animators of Polish documentary film-making: Marek Piwowski, Krzysztof Kieślowski, Grzegorz Królikiewicz, Krzysztof Gradowski, Wojciech Wiszniewski, Tomasz Zygadło, Krzysztof Wojciechowski and others.[5]

International recognition was accompanied by an abundance of issues discussed. Among the problems addressed at that time, special attention should be given to the social issues. As part of this subject matter, many of the films produced at that time were akin to a sociological survey, reflecting the Polish reality of that time on the screen, both in the microsphere (in films depicting the peculiarities of small environments, and sometimes also individual characters), and in the macro sphere (in journalistic reports from large construction sites and in epic historiosophical syntheses, taking into account the economic, social and cultural development of the country). The proposals from the documentary film-makers reflected, like a mirror, almost all the essential phenomena that created the reality of Polish villages, towns and cities of that time, in which tradition, understood as a mainstay of basic ethical values and a reservoir of social rituals, collided with the rapidly progressing process of industrialization and manifestations of dehumanization. Numerous intervention reports were the aftermath of these observations. They agitated in matters concerning various social aberrations, the difficult fate of Polish women and people with disabilities.[6]

The second extensive thematic circle was made up of those images which aimed to explore the past, that is, to create a film compendium of the newest history, mainly from the period of World War II. When

[3] See: J. Głowa, Karabasza szkoła, in: Encyklopedia kina, ed. T. Lubelski, Kraków 2003.

[4] This fact has been noted by B. Drozdowski, Koniec mitu. Cinéma vérité w odwrocie, "Ekran" 1965, no. 28. [5] Broader on that - A. Michalak,Przełom w polskim dokumencie - program artystyczny „szkoły krakowskiej” w kontekście przemian kulturowych i politycznych lat 1968-1971, in: Kino polskie: reinterpretacje. Historia - ideologia - polityka, eds. K. Klejsa, E. Nurczyńska-Fidelska, Kraków 2008.
[6] These issues are described in detail in: J. Bocheńska, Gdzie szukać współczesnej Polski... Uwagi o dokumencie, "Ekran" 1962, no. 33; B. Brzostek, Za progiem. Codzienność w przestrzeni publicznej Warszawy 1955-1970, Warszawa 2007; B. Drozdowski, Z. Klaczyński, Polska $w$ filmie dokumentalnym 1960-1973. Przewodnik - informator, Warszawa 1975; J. Ziarnik, Bez publicystyki nie ma dokumentu, "Ekran" 1965, no. 12; A. Iskierko, Współczesność na ekranie, "Ekran" 1967, no. 25. 
approaching these problems, both the tradition of the propaganda cinema (compilation film) and innovative narrative and genological solutions were used. They served mainly to show the national martyrdom of war and the criminal activity of the Nazis. The authors' ambition was also to document the participation of Polish soldiers in battles at home and abroad, and to reconstruct in a film the most important phenomena and events describing the reality of occupation from 1939-1945.[7]

The thematic variety and the evolution of genres present in the domestic documentary film of the 1960 s allow us to consider it in terms of if not a success then certainly a gradual and systematic development. Its achievements, as well as the increased reception, were supported by other positive phenomena, such as the creation of art-house cinemas offering separate, documentary repertoires, the possibility of screening short films as "supplements" to full-length feature films, TV expansion resulting in wider distribution channels, and the creation in 1961 of a nationwide, and later also international, short film festival in Cracow, which soon became an arena for creative confrontations and a source of new tendencies and search directions for Polish cinema.

The work of domestic documentary film-makers in the 196os was harmonious with the reality outside the screen, which at that time was evolving rapidly. A new generation reached adulthood, free from historical determinants and war traumas. Along with urban landscapes, cultural and social perspectives were changing, and conservative traditions were successfully being replaced with "the thought of the future", as it later turned out, bringing new prospects and opportunities but also traps and threats. Camera lenses recorded the world of unalienable, eternal values, usually associated with the provincial area and the past, as well as the contemporary realities, characterized by the dynamics of change and the imperative of action. The coexistence of these two elements: "the old" and "the new", the past and the future, largely constituted the social profile of that reality. At the same time, it discovered, in various scenes and configurations, the most transparent problems of that time not only related to everyday existence, but also to moods and desires as well as social pathologies and the changing definition of humanity.

The beginning of the decade was marked by the plots related to the great industrialization and expansion of the country. It was a kind of a return to the infamous tradition of screen journalism, which propagated the theses of propaganda of success. In these proposals, however, the subject of "production" took various variants, without limiting its scope to the apotheosis of large state investments and the ethos of work; more and more often the negative effects of these processes and social costs

[7] The significance of the subject of recent history in the Polish documentary of the 1960 s was appreciated by contemporary producers: H. Jantos, R. Wionczek, Poszukiwacze prawdy o przeszłości i dniu dzisiejszym.
Henryk Jantos is interviewed by Alicja Iskierko, "Ekran" 1968, no. 17; R. Wionczek, S. Ozimek, Historia - publicystyka - reportaz. Roman Wionczek is interviewed by Stanisław Ozimek, "Kino" 1969, no. 11. 
resulting from the development of industry, mass migration of people and the expansion of urban development were pointed out. Some of these films were made in "method of observation" fashionable at the time (Węzet [A Knot] by Kazimierz Karabasz, Pierwsza zmiana [The First Shift] by Janusz Kidawa), in part it was regular journalism (Ziemia $i$ wegiel [Earth and Coal] (1961), and Dzień w Turoszowie [A Day in Turoszów] (1963), by Lucjan Jankowski, Ludzie z bazy [People from the Base] (1962), and Płock rusza [Płock Starts] (1964), by Roman Wionczek), while only few were above mediocrity, proposing new narrative and dramaturgical solutions. The greatest achievement in this field is certainly the film report by Jan Łomnicki entitled Narodziny statku [The Birth of the Ship] (1961), which received many awards at film festivals in Poland and abroad. It is less than a 10-minute documentary about launching a new ship at the Gdańsk Shipyard. A seemingly banal and unattractive subject, in Łomnicki's concept it took on the dimension of a universal story about the strength, determination and greatness of a man who, thanks to ingenuity and work, is able to perform spectacular acts. However, one cannot forget that it is also material marked by reflection on the truth and the essence of human existence. In the director's idea, physical work, darkness and the sounds of hammers, recorded with reverence in the ascetic scenery of the shipyard dock, were cleverly contrasted with the pompous celebration of the launching, emphasizing the dramaturgy and authenticity of the foreground and the pathos and artificiality of the events during official ceremonies. The message coming from the screen is simple and unambiguous: what is real and valuable is in the work of shipyard workers; the festive parades and spectacular laudations are in this juxtaposition only an empty and insignificant addition.

Over the years, films that brought a breath of freshness into the "exploited" and, in a sense, degraded issues started appearing. This breath of fresh air was characterized by modern or poetic vision. These films were, in a sense, a part of a polemical discourse with the industrial and production journalism of the previous decade. The euphoria of large-scale construction projects was replaced with a bitter diagnosis of the social costs that were incurred at the same time. In a film report by Roman Wionczek entitled Puławy, godzina zero [Puławy, Zero Hour], (1966), the consequences of the industrialization of the country mainly affect average citizens and their families. The director does not criticize the very idea of expanding and modernizing the domestic industry; he is even able to justify, in a well-balanced commentary, some of the drastic urban planning moves, such as the mass rehousing of the population. On the other hand, it is completely inconceivable, to him and to the viewer, that the idea of creating a modern centre for the nitrogen industry, implemented in an ill-conceived and chaotic manner, destabilizes and hinders the way a big city functions. Beautiful slogans calling for romantic sacrifices in the large construction sites, the author seems to argue, do not work when there are no places in kindergartens, and 
the health service is powerless and ineffective, when the everyday lives of local people abruptly lose their rhythm, and building site workers are not guaranteed basic living conditions. He created his critical message by emphasizing the discrepancy between the image and the off-camera commentary, between the official account of the events and the reality which undermines its authenticity.

A different perspective was set forth by the documentary impressions by Władysław Ślesicki (Energia [Energy], (1967) and Andrzej Piekutowski (Czas przemiany [The Time of Transformation], (1968). Bogumił Drozdowski once included both films in the so-called impressionist and poetic trend in the domestic documentary, the optics of which focuses not so much on the purpose of building as it does on the process itself (this is an important supplement to the documentaries that "portray magnificent industrial landscapes, fantastic urban complexes, factories, shipyards, houses" $[8]$ ). Leszek Krzyżański's camerawork is of indispensable value in both films. It brings out the beauty of the native landscapes and the atmosphere and might of the industrial architecture, overwhelming with its vastness and geometry. In both cases, we also notice a similar structure in the films. Both Ślesicki and Piekutowski conduct the course of the narrative in harmony with the rhythm of works on a big building site, during the construction of the dam on the San River and the opening of an opencast mine near Konin. The authors works solely with images, entirely giving up the off-camera commentary.

The idea of Energia [Energy] was put forward by Kazimierz

Il. 1. Czas przemiany, Andrzej Piekutowski. Source: Ninateka Orłoś, an excellent prose writer, with whom Ślesicki collaborated on his feature films Nieobecny [Absent] and Ruchome piaski [Quicksand]. The director was put under pressure by Orłoś, though he was well aware that he was entering a very uncertain area, not only exploited many times at the beginning of the decade by domestic documentary film-makers, but also notorious for being a propaganda production theme. So to avoid repetition, derivation and unwanted associations, it was necessary to give the venture a different, original character. Still, during the filming of Energia, the director shared his observations: "I am afraid that the title of the

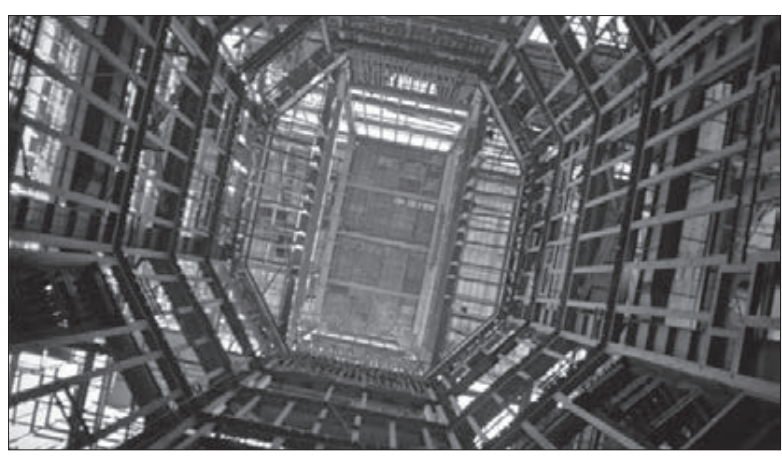
film, its subject, suggests that it will be yet another unrewarding and ridiculed "production film». Well, I do not want the film to be literal. I do not mean explaining what is happening here, or recording a film

Il. 2. Czas przemiany, Andrzej Piekutowski. Source: Ninateka

[8] B. Drozdowski, Polak pracuje, "Film" 1970, no. 16, p. 5 . 

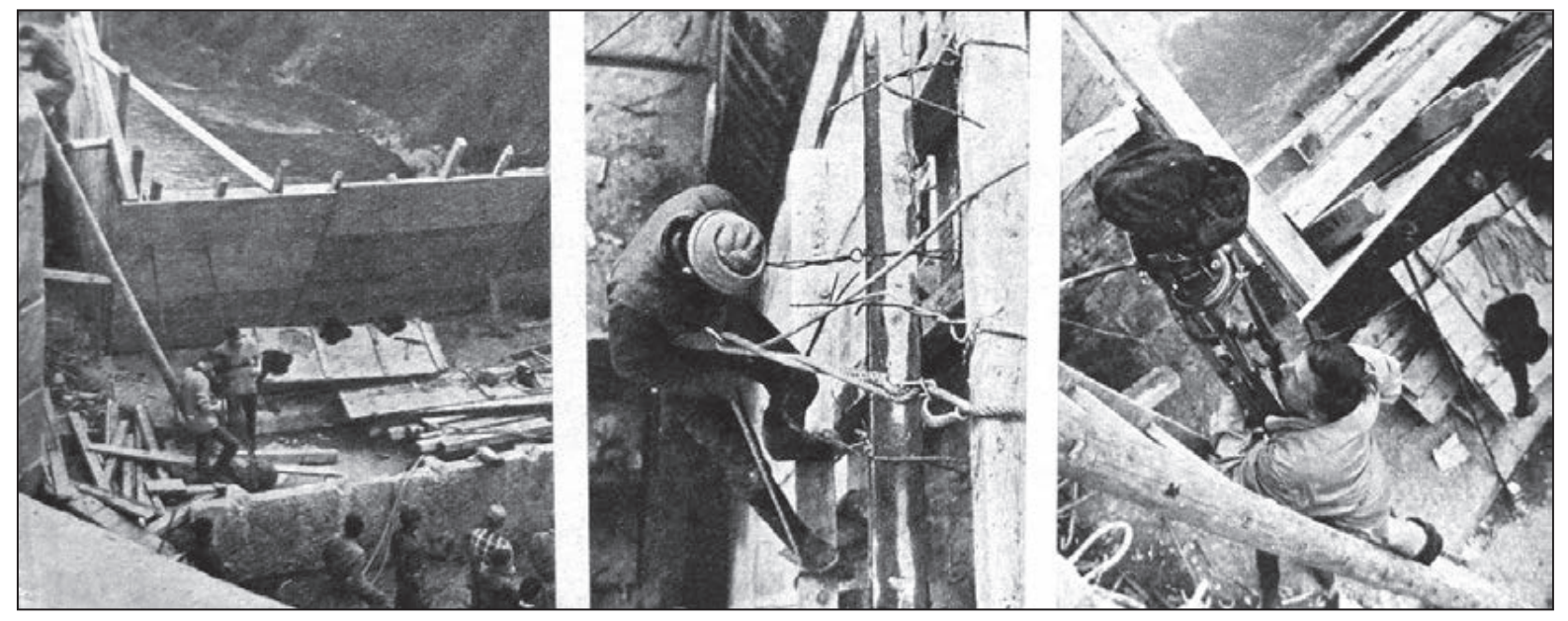

Il. 3, 4, 5. Energia,

Władysław Ślesicki. Fot. R. Sumik

with a commentary: it will not be a report on construction works." [9] Such was the idea from which the film impression with a deliberate dramaturgy and poetic creation of moods was born.

The film begins with some very mysterious images, shot at night, showing the palette of moving car headlights in an unspecified space. In close-ups, the underexposed warning boards first appear in a flashlight: "Do not touch! An electric device!" and a human face, tired in its observational focus. Only after a moment does a wider picture emerge, and it reveals fragments of some great construction. Intensive construction works is underway. Huge machines follow the work of human hands. There are short, decisive commands: "Loaded? Well, we're moving! The

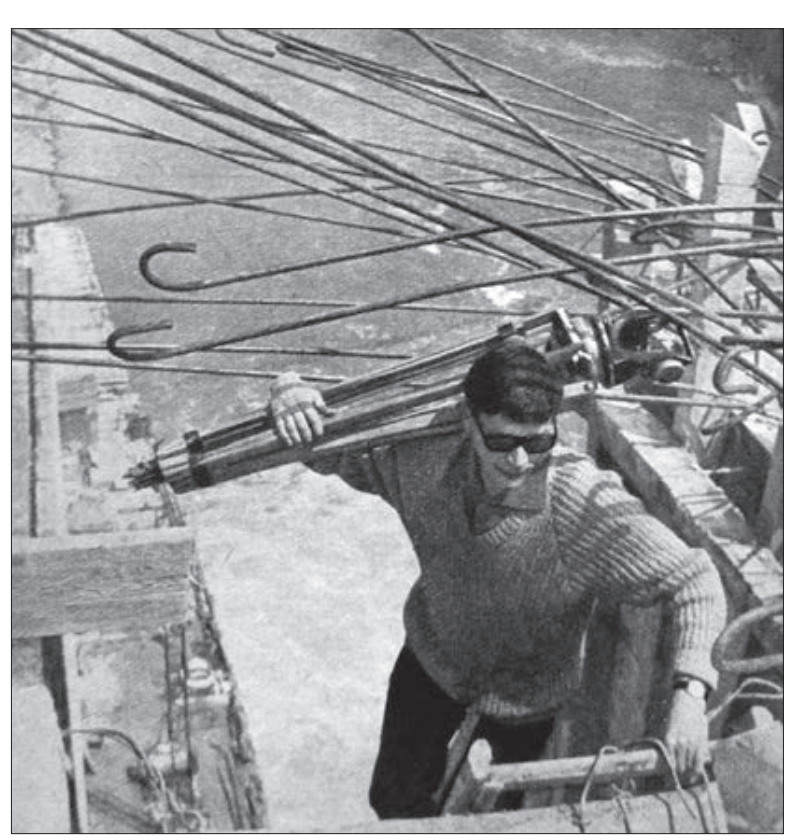
cement mill has started!". Bulldozers are leveling the terrain, welders erect steel structures, liquid concrete is poured from drums gallon after gallon. The camera records both wide angle and close-ups of human hands and faces. In the background a "symphony" of sounds of working machines and devices unfolds.

The day dawns. The space is changing. Industrial scenery gives way to a beautiful natural landscape with the Solina valley spreading in the distance. However, the blissful mood dispels quickly. After a few seconds, in the sound layer, filled with gentle music, a disturbing bang of an explosion spreads, followed by human voices, full of dramatic protest, lament and complaint. On the screen, we can see moving and self-explanatory images: the walls of houses razed to the ground by a bulldozer, fire and

Il. 6. Energia, Władysław Ślesicki. Fot. R. Sumik ruins. It is the cost of a great construction venture the director seems to be suggesting. But these are just suggestions, pointing to the fact

[9] E. Smoleń-Wasilewska, Dwa miesiące w Solinie,

"Film" 1967, no. 23, pp. 6-7. 
that such projects involve displacements, often forced, in which the inhabitants lose all their possessions. However, this is not the main theme of the film. The camera focuses on the further stages of a great construction endeavor. This time it accompanies mountain-driving trucks carrying rock material. But the analogy to earlier, "nighttime" scenes is barely palpable. The dark mystery give way to idyllic images set to a cheerful, Western-style, whistled melody. When the trucks arrive at the destination, the "daytime" sequence takes place at the construction site. Only now, and this is the seventh minute of the film, can we get the idea of what we are dealing with and what the director's story is about. In front of the viewer's eyes there is a dynamic landscape of large-scale, human actions aimed at the subjugation of the mighty force of the water current. It is the construction of a concrete dam on the San River, one of the flagship state investments of the 1970s. In Ślesicki's work, this aspect was largely marginalised, giving way to the careful observation and the psychologisation of the characters. The director argued: "it is about [...] conveying these [...] first, strongest impressions that we are witnessing the creation of something great, not only of course in the sense of physical shapes, but also in the sense of the people working here, doing significant things." [10] In the story of the great construction enterprise and its people, Ślesicki once again based his work on a poetic mood creation that was free of journalism - the atmosphere of the place and related activities turned out to be much more important than a clearly defined action, whether in time or in space.[11] The essence of precisely composed images was not so much built up by wide angles documenting the magnitude and significance of the project, but by recording the states, feelings and emotions on the faces of the workers, as well as the impression that they are participating in something that is important, ground-breaking and useful for the public. The viewers are convinced of that by the shots of dramatic moments of pumping out water from an uncontrolled leak, of repairing breakdowns on tautly stretched steel ropes, or of the action of pouring subsequent portions of the meticulously prepared concrete, itself carried out with uncommon precision.

The film consists of several parts, which form a dramaturgically composed whole. The first of these includes the night sequence, preceded by the introduction of the guard, taking place at the construction site, the second (after brightening) depicts the monotonous life of the town, the displacement, the "ride" of the trucks down mountain serpentines, and the day sequence with retardation (workers at lunch at the canteen) and the culmination point (closure of the dam), the third part is made up of the shots presenting the relaxation and satisfaction prevailing among the workers after a well done job, and a closing scene, i.e. guard's night return home. As Mikołaj Jazdon points out, these images resemble 
scenes from a sensational drama.[12] The first culminating scene begins in the dispatch office: on the basis of fragmented statements one can conclude that it is about a surgery requiring precision (someone warns: "Because they're all such clunkers, what if someone gets knocked?!"); and indeed a bucket of concrete is lifted from the ground. Filmed in the night (which submerges all the rigging in darkness), it seems to be able to move in the air, and it emerges twice from an unexpected side (a great example of filming and editing mastery). Again, the whistle of machines and raising voices, including the command: "Let go!" - concrete falls into the caisson, builders quickly throw a vibrating drill into it, take it out, transfer it to another place. When the sounds are turned down, the empty bucket moves away, eventually getting out of the view. [13] "It really has some specific charm of large-scale work. The rasp of the «buckets», the whistle of compressed air, vibrators. [...] These amazing sounds have their drama" [14] wrote Elżbieta Smoleń-Wasilewska. These words are confirmed in the second culminating scene, with the shots of trucks running down with rubble. Again, an observation sequence, sometimes phenomenal micro-events (workers like tightrope walkers, on high-stretched ropes, with cold blood, mount some necessary elements of the structure), moments of excited emotions and faces expressing effort and focus. And when it seems that the sequence is entering its decisive phase, an unexpected cut shifts the action to the canteen. The scene lasts less than a minute, but it is enough for the images of the workers embarrassed by the camera, discreetly smiling, to somehow dampen the viewer's vigilance. The moment when dinner is served, a cut and the change of space. Numerous streamlets merge into streams that are more and more swollen, arising into flood waters. The culmination is approaching (deliberately detached): the dam is being completed with subsequent, slowly lowered concrete blocks, the dispatcher's voice ("Stop lowering, the top depart!") overlaps the images of backbreaking acrobatics at a high altitude, the crane operator is manipulating the knobs until the fast current weakens. The partition of the river becomes a fact. Time to relax: "Portraits of people with relaxed expressions, faces associated with concrete masses; the last face - the guard whom we saw at the beginning of the film." [15] Instead of the sharp cuts, we have cross-fading here, instead of construction noise - passages of soft music (including the flute tune).[16]

Energia shows a creative concept that is consistently and precisely executed. The director deliberately distances himself from the poetics of the propaganda cinema, telling his own lyricism-saturated visual and sound story with a deliberate dramaturgical construction. There are problems known from his earlier work included in an original way, but treated somewhat perversely. In contrast to the film Ludzie i ryby

[12] M. Jazdon, Władysław Ślesicki (a brochure in a DVD series Polska Szkoła Dokumentu).

[13] A detailed dramaturgical analysis is made by P. Pławuszewski, op.cit., pp. 203-205.
[14] E. Smoleń-Wasilewska, op.cit., pp. 6-7.

[15] Ibidem, pp. 6-7.

[16] P. Pławuszewski, op.cit., pp. 204-205. 
[People and Fish], this time the focus is not on the beauty, wealth and strength of nature, but on a man who in a sense can tame it without its annihilation. This is symbolically signaled by the last scene of the film, constructed on the principle of a compositional frame, in which the construction guard returns after a day's work to a nearby house, changes for bed and puts out a kerosene lamp on the table in a telling gesture. This is, on the one hand, an expression of the perversity of fate in the context of the hydroelectric power plant being built in the vicinity, but more probably a sign of the times and of the imminent changes to come.

In Czas przemiany the message of the film is more unambiguous. The director combines images reconstructing the various stages of construction works, with shots presenting the lives of the inhabitants of the surrounding villages and towns, and the richness of the surrounding nature. In the subsequent scenes, these two completely different realities begin to overlap. Large concrete constructions suddenly rise above the straw roofs of houses, and railway tracks and power pylons surround them with a dense network of concrete and steel. What was just a moment ago the natural richness of this land has been ruthlessly appropriated by artificial products of civilization. Silence and beautiful landscapes have been replaced by the intrusive sounds of machines and grey mine buildings.

What distinguishes Piekutowski's documentary from socialist realist production films is, firstly, the creative idea, secondly, the camera work (filming by Leszek Krzyżański), and thirdly, the music (recorded in the Experimental Studio of Polish Radio by Józef Patkowski and Krzysztof Szlifirski).

The director attempts to convey in his film a thesis that has been assumed in advance. He contrasts images depicting the Polish countryside with shots showing the construction of a large opencast mine near Konin. However, this is not a simple comparison based on the principle of negation. Piekutowski's film, with its dramaturgical structure, is more like a classic thriller than an observational documentary. The pristine and untouched provincial area (a village, a small town and a nearby monastery) is valued extremely positively, in contrast to the mine being built nearby, posing a great threat to it both in terms of a degradation of the landscape and the annihilation of local tradition and customs.

In the first shots, these two worlds function side by side. First, the director, in close-ups, introduces the viewer into a mysterious and strange space, marked by brown slag-heaps and streams of frozen rocks, reminiscent of a lunar landscape. Strange, pulsing sounds emerge from the background, as if from a space station. The shots that follow are definitely more realistic. Hills covered with lichens and small flowers appear on the screen, and at the bottom, a coachman, at an unhurried pace, leads a horse that is pulling a cart loaded with hay. A contact between the two realities occurs first only in the sphere of sound. The sound of an explosion (prepared in the studio) comes off camera, and only after that, there is a picture showing trees being uprooted with 
the force of the explosion. A huge steel wheel appears in view, digging into another stretch of land, destroying everything that stands in its way. More trees are falling, dust clouds rise into the air. When they fall, the viewer can see in the distance the buildings of the town and an electric traction system that encircles them. The worlds are seemingly approaching each other. But they are still divided and still function fully autonomously. The camera moves into the town. It observes the monotonous life of its inhabitants (children playing at the monument, an elderly woman walking, boys leaning on bike handlebars), it registers building elevations, records the time-patched signboards: "Zakład Krawiecki Kawa Paweł [Paweł Kawa's Tailor Shop]," "Meble i Przecena ]Furniture and Discount]," "Restauracja i Kawiarnia Pod Orłem ]Eagle Restaurant and Coffeehouse]," etc. It enters the interior, revealing the retreat of a family life: a bed, a chest of drawers, a figure of the Virgin Mary, family and holy paintings hung on the walls, kilims with natural motifs. Then it moves to a nearby monastery. The monks are picking apples in their orchard, then they pray. There is absolute silence, interrupted every now and then by disturbing sounds of explosions. Finally, the perspective changes. There is a distant landscape with the surrounding forests that is viewed from the monastery tower. The panoramic movement to the right, however, discovers a new element in this space, an industrial complex with chimneys and steel structures representing it. The threat has more and more distinctive shapes and grows in strength.

Another sequence reveals the realities of work in the mine. Workers, like puppets, climb the giant steel structures, add new elements, twist and weld, creating industrial, monumental "monsters". The conveyors transport tons of earth and rocks, and dozens of wagons carry them in an unknown direction. Information boards pass: "Rzgów - 107", "Skulsk - 110", "Ślesin - 124," etc.. Everything points to a massive project involving thousands of people and hundreds of complicated machines. At some point the noise stops. A crowd of people "spills out" from the factory, the workers get on buses which are waiting in a long queue and leave for their homes in neighboring villages. It is time for a short nap or talking to colleagues. After returning home, their new duties are awaiting - work in the field and farm. One of the men leads a horse out of the stable and harnesses it to a cart, draws water from a well; geese are grazing nearby, pigeons are cooing on the roof, laundry is drying on the washing lines, a woman is preparing dinner and taking care of the children. The action moves into a field where the autumn potato harvest is underway. Everything goes on with its eternal rhythm. Up to a point. As the man starts ploughing, high poles with steel ropes stretched between them appear in the background, behind him. They occupy more and more space in the view, first one quarter, then a half, and finally $4 / 5$ of the picture. They tower above the village homesteads, they threaten with their hideous appearance and overwhelm with their presence. The film closes with an inscription 
board: "Widziane w powiecie konińskim we wrześniu 1967 (Seen in the district of Konin in September 1967)".

The director's idea was to gradually reveal the changes taking place in the landscape of nature due to the construction and extension of the opencast mine. In the symbolic plan, however, it was about showing not the appropriation of space by industrial products of civilization, but about the danger resulting from the degradation or significant annihilation of tradition and the eternal laws governing life in the Polish countryside. He supported his thesis with contrasting sets of images and shots depicting the local countryside and the functioning of the mine, as well as the gradually increasing landscape transformation that has been caused by an expansion of foreign, external and destructive factors.

In this way, the filmmakers of the Polish documentary school managed to capture a certain process of relationships and connections being built up between these two worlds. A significant role in this major endeavor was played by the insightful and accurately filmed images by Leszek Krzyżański and the audio sphere that co-operated with them: its components were completely prepared in the studio. The menacing sounds of working machines and tremors of electric tractions introduced an element of mystery and impending danger. Disturbing scratches, the cracking of trees and "painful" creaking of wood created a certain aura of destruction and suffering, a doomed and unequal battle between "the old" and "familiar" and "the new" and" fearsomely unknown". The ever-recurring sense of an impending threat built successive levels of dramaturgy and arising emotions, and the visual and sound composition of the scenes and sequences created a unique, lyrical mood combined with symbolism that was aimed at a wider interpretation.

Bocheńska J., Gdzie szukać wspótczesnej Polski... Uwagi o dokumencie, "Ekran" 1962 , no. 33

Brzostek B., Za progiem. Codzienność w przestrzeni publicznej Warszawy 1955-1970, Warszawa 2007

Drozdowski B., Koniec mitu. Cinéma vérité w odwrocie, "Ekran” 1965, no. 28

Drozdowski B., Polak pracuje, "Film" 1970, no. 16

Drozdowski B., Klaczyński Z., Polska w filmie dokumentalnym 1960-1973. Przewodnik - informator, Warszawa 1975

Głowa J., Karabasza szkoła, in: Encyklopedia kina, ed. T. Lubelski, Kraków 2003

Iskierko A., Wspótczesność na ekranie, "Ekran” 1967, no. 25

JackiewiczA., Szkoła polska filmu dokumentalnego, "Film” 1961, no. 6

Jantos H., Wionczek R., Poszukiwacze prawdy o przeszłości i dniu dzisiejszym. Henryk Jantos is interviewed by Alicja Iskierko, "Ekran" 1968, no. 17

Jazdon M., Władysław Ślesicki (a brochure in a DVD series Polska Szkoła Dokumentu), 2010

Klaczyński Z., Dwa nurty w filmie dokumentalnym, "Ekran” 1961, no. 25

Michalak A., Przełom w polskim dokumencie - program artystyczny „szkoły krakowskiej" w kontekście przemian kulturowych i politycznych lat 1968-1971, in: 
Kino polskie: reinterpretacje. Historia - ideologia - polityka, eds. K. Klejsa, E. Nurczyńska-Fidelska, Kraków 2008

Pławuszewski P., Po swojemu. Kino Władysława Ślesickiego, Kraków 2017

Smoleń-Wasilewska E., Dwa miesiące w Solinie, "Film" 1967, no. 23

Wionczek R., Ozimek S., Historia - publicystyka - reportaż. Roman Wionczek is interviewed by Stanisław Ozimek, "Kino" 1969, no. 11

Ziarnik J., Bez publicystyki nie ma dokumentu, "Ekran” 1965, no. 12 